\title{
Passenger Service Dominance through Brand Loyalty: An Idiosyncratic View of Starline Bus Service (Pvt.) Limited
}

Mohammad Abul Kashem

Feni University, Bangladesh

mak.mktg@yahoo.com

\begin{abstract}
Continuous improvements of bus services ensure passengers' well-being. Quality services amalgamated with low price are dominating factors to change passengers' views in this aspect. With contentions to previous ideology, passengers' choices stick to a particular bus service provider especially Starline Bus Services (Pvt.) Limited, Bangladesh in compare to other transport (bus) services available on the way of Feni to Chittagong. Hypotheses were set based on fact-finding relationships and justified through 411 sample responses both for loyalty and satisfaction in relation to key predictors like quality service, one stop service, waiting time, price, income, and brand belief and found very convincing roles of the same to develop impregnable brand loyalty of Starline. As a result, those predictors possibly opted to create supremacy in travel service in this region and even considerable factors in future for building loyalty toward passenger travelling services.
\end{abstract}

Keywords: Travel Service, Satisfaction, Loyalty, Transport Service, Safe Journey.

Copyright: (c) 2020 Mohammad Abul Kashem. This is an open access article distributed under the Creative Commons Attribution License, which permits unrestricted use, distribution, and reproduction in any medium, provided the original work is properly cited.

Correspondence: mak.mktg@yahoo.com

ORCID of authors: Mohammad Abul Kashem - https://orcid.org/0000-0002-3579-4838

DOI: http://doi.org/10.4038/kjm.v9i1.7620 


\section{Introduction}

Passenger travelling services of Bangladesh is historically facing challenges from its inception with the blame of non-consistency of services, but competition tries to keep standard. From the scenario of transport operations, the general quality of services at all levels by all modes of Bangladesh have been found poor and unreliable succinct with safety $\&$ security issues (Mahmud. Rahman \& Hasanat-E- Rabbi, 2012). However, desired service expectations with emerging transport technologies remain uneven due to lack of available data on ridership (Shaheen, Totte, \& Stocker, 2018). Rationally, lessening travel time with safety and reasonable travel cost in context to quality bus services can contribute on economic advancement of a country (Enoch, 2003).

The determination of absolute universally accepted parameter on transport sector is not out of debate (Brady \& Cronin Jr, 2001; Cronin \& Taylor, 1994). However, for the scenario of satisfaction and loyalty, new and pragmatic elements were utilized in different multivariate aspects (Andreassen \& Lindestad, 1998; Bloemer \& Kasper, 1995; Butcher, Sparks, \& O'Callghan, 2001; Cronin et.al., 2000; Dick \& Basu, 1994; Fornell et.al., 1996; Hellier, 2003; Stank et.al., 1999; Ostrowski, O'Brien, \& Gordon, 1993). As per the prior considerations, the present study is set for materialization of the absolute dispensations of Starline Bus Services, very regionally at Feni, Bangladesh. The items like waiting time and stoppage lead the competition of Starline in case of service dominance even though few services are very much identical to other service providers in this region. So, the justification of the role of key passengers' service indicators in terms of satisfaction and loyalty are quite indispensable for changing parameter of travelling practices. From the general state of affairs, the differences from the view point of service indicator characteristics between Starline and other service providers are not obvious to enjoy excessive performance/ flexibility of dominance what they are enjoying right now. Hence, the study tried to explore the reasons behind the passenger's absolute preference toward Starline through incorporating key service indicator characteristics and also to measure the effect of the same on satisfaction and loyalty.

\section{Starline Bus Services Limited}

Feni, a small and populated district located in the south-eastern part of Bangladesh, is bounded by Comilla district on the north, Chittagong district and the Bay of Bengal to the south, Tripura (Indian State) and Chittagong district to the east and Noakhali district to the west (Banglapedia). So, passengers are always remain vigilant and traveling from Chittagong to Feni and Feni to Chittagong. There are a number of transport services available on the way of Feni to Chittagong and vice-versa, which are categorized as (i) Direct service without Stoppage at Feni, (ii) Direct service with stoppage at Feni and (iii) Local services.

Visibly, Starline is considered to be one of the oldest service providers particularly on passenger travelling services in Feni region and getting excessive preferences from passengers for quality services and strong brand belief. Very specifically, the waiting time for Starline services is 15-20 minutes with a fare of tk.150/person which is exactly $50 \%$ more than the other direct passenger traveling services with stoppage at Feni (Tisha Plus, Soudia, Grambangla etc. charge tk. 100/person). The reasons behind this excessive price flexibility are supposed to be waiting time, one stop service, and certainty of services. The other bus services are carrying passengers via Feni on the way of Comilla to Chittagong by a stoppage at Feni. 
Hence; the minimum and maximum number of passengers can avail the services are not fixed because that depends on the vacant seat available at the Comilla terminal. Out of the direct services other than Starline, another bus service, Tisha Plus is reaching the destination earlier (because it does not have any stoppage other than Feni on the way of Comilla to Chittagong, but Starline has 3/4 stoppage on the way of Feni to Chittagong). Very interestingly, even in rush hours (Thursday evening, Friday or even Saturday) or traffic jam when Starline charges (In few cases tk. 200/person) more than regular price, passengers were in queue to pay more to Starline where other services are waiting for passenger at a regular fare. So, the price influence on demand and supply law is volatile subject to the circumstances stated above. Therefore, these preferences have been accelerating the path way of Starline to do business in a monopoly nature. So, the study aims to identify the substantial factors affecting passengers' perception for travelling through Feni to Chittagong and check the contribution of each factor construct on loyalty and satisfaction.

\section{Literature Review}

Basically, personal needs educate customers depending on experience. In these scenario, perceived service alternatives were aware of competitive offerings and addressed to match appropriately with needs. The brand belief or reputations of Starline in this area is sky top for longer service tenure. In fact, company's reputation generally described as a combination of the stakeholders' assessments between company's earlier role and how well the company's general performances coping with the social and political environment (Logsdon \& Wood, 2002). Finally, self - perceived service roles educate customers to understand their roles and how to perform better. In order to predict travel behavior, it is important to understand how individual characteristics of a person interact with the characteristics of the situation, therefore understanding the positive and negative evaluative factors influencing destination choices of the people are worth considerable (March \& Woodside, 2006; Laws, 1995; Holloway, 2004).

Quality service, a burning issue if not maintained leads to dissatisfaction (Thompson \& Schofield, 2002) whatever the service-oriented industry or manufacturing. In addition, service companies particularly on transport, it is an important construct (Chou, 2012) which ultimately tends to customer loyalty (Liao \& Hsieh, 2011) whereas de Oña \& de Oña (2014) assessed the service quality for retaining passengers of transport. Irrespective of the differentiation, quality service is another option to get ahead in the competition (Buttle, 1996). Consequently, it creates chances to change in daily transport habits (Dell'Olio, Ibeas \& Cecin, 2011).

Irrespective to habitual dependency on quality service, passengers' choices vary for transport selection depending on income or affordability (Carruthers, Dick \& Saurker, 2005). In earlier research, income as a passenger characteristic was tested for most accurate demand forecasting (Blainey \& Mulley, 2013; Ghalehkhondabi, Ardjmand, Young, \& Weckman, 2019). Moreover, Semeida (2014) considered income for predicting passengers' demand, even for international passengers. In addition, low income tends to limit the travel frequency or number of trips, even changes in selecting modes of transport (Carruthers, Dick \& Saurker, 2005).

Price restricts the consumer choices especially for price sensitive consumers (Vodopivec, \& Miller-Hooks, 2017). However, Rystam (1998) supported price/fare as the most common persuasive factor of transportation. Additionally, 
Litman (2013) has given importance on price constructs very specifically, on discomfort, time of travel and risks whereas changes in price as we know are caused by location decisions, vehicle type, type of service selected, and frequency of travel. In this aspect, Suryani, Chou, \& Chen (2010) developed the scenario model of travel fare for predicting passengers' demand irrespective of mode of vehicles.

Trust leads to a higher level of loyalty relative to travel fare (Morgan \& Hunt, 1994) by creating favorable and positive intentions (Ballester \& Aleman, 2001). Again, depending on customer belief or trust perception, the success of a marketing strategy has been evaluated on the level of customer satisfaction (Flavian, Martinez, \& Polo, 2001). On the other hand, it is also argued that behavioral intention works for stimulating positive reputations to develop trust among the passengers (Park, Robertson \& Wu, 2004). But depending on long-term sustainable belief, either a brand name or positive corporate image, a differentiating element having incomparable sensational views (Jo Hatch \& Schultz, 2003), might work better than the transport firms that concentrate only on passengers carrying or, go for generating short term revenues (Van Phuong, \& Hieu, 2018).

A preferred product/service might cause repetitive brand patronage despite of situational influences subject to re-buying tendency of consumers. But marketing efforts which developed the psychological attachment to a service (Beatty, Kahle, \& Homer, 1988) had the potentials to cause switching behavior (Oliver, 1997). On the other hand, one stop service which worked for perception indicator (Deb \& Ahmed, 2018; Efthymiou, Kaziales, Antoniou, \& Tyrinopoulos, 2014) is the preferential service for loyal passengers for reaching destination in-time (Shaaban \& Khalil, 2013; Suman, Bolia, \& Tiwari, 2018). This one stop service basically differentiates the local and direct services in passenger travelling services where no passenger should uplift other than bus counter.

The regularity of services provided by the transport authority is used to assess the quality of services which ultimately results in satisfaction of the passengers (Eboli \& Mazzulla, 2011). Apart from the influences on loyalty, it creates an indispensable attempt for passenger satisfaction (Tyrinopoulos \& Antoniou, 2008). Generally, the ultimate satisfaction among the passengers can be bred through perceived value on the quality services (VanLierop \& El-Geneidy, 2016). As a result, this value is considered as one of the important constructs for achieving both satisfaction and loyalty (Gallarza \& Saura, 2006).

More specifically, customer loyalty is the degree to which the customer has exhibited repurchasing behavior toward a particular company service/product (Hellier et.al., 2003). It's basically a commitment of the passengers for repurchase consistently in future with a very strong positive attitude (Sangadji \& Sopiah, 2013). In case of transport service industry, passengers' satisfaction is the consequences of service optimization which works as a predictor of passenger loyalty (Lai, \& Chen, 2011; Rezaei, Mazaheri, \& Azadavar, 2017). Additionally, true brand loyalty not only repeats purchasing behavior but also commits positive psychological and evaluative decision-making approach (Bloemer \& Kasper, 1995).

Along with the key variables, there are few non-substantial factors available like access to public transportation or access to major streets, lifestyle, competition, emergency, service accessibility, cleanliness, staff hospitality, safe journey, and so on. But this study worked with the factors to identify the real preferences on Starline Bus Services Limited having 
more flexibility that is basically exceeding the most common consideration for selecting a transport (bus) service from earlier researches. Thus, the matter itself stimulates interest to the author for empirical evidence. To maintain the sustainable development of the traveling structure and services from the perspective of passenger choice mode behavior in this region, behavioral justification of the passenger choice pattern is quite essential for seeking unknown behavioral intention of passengers especially on Starline.

\section{Hypotheses of the Study}

Hypothesis 1: Income (I) has a positive effect on satisfaction;

Hypothesis 2: Income (I) has a positive effect on loyalty;

Hypothesis 3: Price (P) has a positive effect on satisfaction;

Hypothesis 4: Price $(\mathrm{P})$ has a positive effect on loyalty;

Hypothesis 5: Quality Service (QS) has a positive effect on satisfaction;

Hypothesis 6: Quality Service (QS) has a positive effect on loyalty.

Hypothesis 7: Brand Belief (BrB) has a positive effect on satisfaction;

Hypothesis 8: Brand Belief $(\mathrm{BrB})$ has a positive effect on loyalty.

Hypothesis 9: One stop service (OSS) has a positive effect on satisfaction;

Hypothesis 10: One stop service (OSS) has a positive effect on loyalty;

Hypothesis 11: Waiting time (WT) has a positive effect on satisfaction;

Hypothesis 12: Waiting time (WT) has a positive effect on loyalty.

Conceptual Model
Based on the literature review, the hypothesis and measurement model formulated for the exogenous variable and the endogenous variables as shown in figure-I to explain the relationship among the factors of passenger transport services on satisfaction and loyalty.

\section{Methodology}

The objective of the research is to examine the relationships among predictors and criterion variable particularly on transport sector of Bangladesh. Owing to objectives, this research considered factor analysis in order to make the appropriate group of variables from different service paradigm in different categories and again used the structural equation model of the latent variables with the intensity to satisfaction and loyalty.

The study is considered survey method for data collection. On the view point of individual initiatives for cost purposes and easy distribution, convenience sampling technique was used to get required number of samples. The population was the passengers travelling frequently form Feni to Chittagong, Bangladesh by using the Starline Paribahan Ltd. and other passenger transports. The sample size was targeted 450 initially, but $411(91 \%)$ were selected based on avoiding missing responses and it is appropriate with standard of 100-200 respondents for unknown or very large population (Hair et. al., 2006). Similarly, to measure the concentration on loyalty and satisfaction, the perception survey questionnaire measured through earlier suggested measures opined by the researchers/experts (Hu \& Jen, 2006, Nguyen, \& Leblanc, 2001) and also changes made by states using a five-point closed order Likert scale, where 1 indicates that the variable is not important at all and 5 is very important with extensive support from the literature. Consistently, questionnaires were distributed among the passengers waiting 
for traveling through Starline in counters at Feni and Chittagong. Likewise, the questionnaire included the very common personal demographic information like age, gender and income, various dimensions of quality services, waiting time, one stop service, brand belief, price (bus fare), satisfaction and loyalty (by 39 items in total).

The most frequent measurement of transport sector evaluated through the factor of quality service which items are derived from the research on Shaaban \& Khalil (2013). In addition, the satisfaction related parameters were included from Mai et al., (2013) and Shaaban \& Khalil (2013). Arguably, the very embodied items such as, waiting time what was considered with quality service measurement on earlier research on Aidoo, Agyemong, Monkah \& Afukaar (2013) was separately treated specially for Starline for its influence and discrimination. Again, the items of satisfaction were adapted from the several earlier researches especially on Freitas (2013); Tyrinopoulos \& Antoniou (2008). The items set for the one stop services owed from Friman, Edvardsson \& Garling (2001), Roch \& Poister (2006). Another crucial factor such as income was materialized from the reviewing the literature particularly on Mai et al., (2013); Shaaban \& Khalil (2013). With similar fashion, the items considered in earlier researches of SumChau \& Ngai et al., (2010); and Mai, et al, (2013) were reconsidered as the suitable elements for brand belief or trust. On the other hand, the price or bus fare was measured through the items covered from Friman, Edvardsson \& Garling (2001); Mai et al., (2013) and Shaaban \& Khalil (2013).

\section{Data Analysis}

To assess direct relationships among the studied variables the researcher has performed confirmatory factor analysis and structural equation modeling
(Anderson \& Gerbing, 1988). SPSS 22 and AMOS 22 had been used to perform these analyses. These analyses supposed to help to understand the model fit by presenting a credible assessment on the antecedents of loyalty of passenger transport services of Bangladesh.

\section{Factor Analysis}

The collected data then were analyzed by applying factor analysis using SPSS 22.0. Both the factor analysis namely Exploratory Factor Analysis (EFA) and Confirmatory Factory Analysis (CFA) were used with a view to grouping variables depending on the value of correlation among the items for the prior and identifying relationship among the variables for the latter.

\section{Sampling Adequacy of Data}

The KMO value is 0.872 which indicates the sampling adequacy of data in table 01 .

Table 01: KMO and Bartlett's Test

\begin{tabular}{|c|c|}
\hline $\begin{array}{l}\text { Kaiser-Meyer- } \\
\text { Olkin Measure of } \\
\text { Sampling } \\
\text { Adequacy. }\end{array}$ & 0.872 \\
\hline $\begin{array}{l}\text { Approx. Chi- } \\
\text { Square }\end{array}$ & 14708.16 \\
\hline df & 741 \\
\hline Sig. & 0 \\
\hline
\end{tabular}

Table 02: Total Variance Explained

\begin{tabular}{|c|c|c|}
\hline Component & $\begin{array}{c}\text { Extraction } \\
\text { Sums of } \\
\text { Squared } \\
\text { Loadings }\end{array}$ & $\begin{array}{c}\text { Rotation } \\
\text { Sums of } \\
\text { Squared } \\
\text { Loadings } \\
\text { Cumulative } \\
\% \text { (Total) }\end{array}$ \\
\hline $\begin{array}{l}\text { Quality } \\
\text { Service }\end{array}$ & 12.101 & \\
\hline $\begin{array}{l}\text { One Stop } \\
\text { Service }\end{array}$ & 4.303 & \\
\hline Price & 3.215 & \\
\hline $\begin{array}{l}\text { Brand } \\
\text { Belief }\end{array}$ & 2.388 & 69.027 \\
\hline
\end{tabular}




\begin{tabular}{|c|c|}
\hline Income & 2.052 \\
\hline $\begin{array}{l}\text { Waiting } \\
\text { Time }\end{array}$ & 1.878 \\
\hline Satisfaction & 1.597 \\
\hline Loyalty & 1.02 \\
\hline
\end{tabular}

The variables have been further subjected to principal component analysis. The Eigen values, the percentage of total variance, and rotated sum of squared loadings have been shown in table 02 . The factor matrix as obtained in the principal component analysis has also been further subjected to Varimax Rotation (Tabachnick, Fidell, \& Ullman, 2007). An examination of Eigen values has led to the retention of eight factors according to table 02. These factors have accumulated for $12.10 \%, 4.30 \%, 3.21 \%, 2.38 \%, 2.05 \%$, $1.878 \%, 1.59 \%$, and $1.02 \%$ of variation. This implies that the total variance accumulated for by all eight factors is $69.027 \%$ and remaining variance is explained by other factors.

\section{Reliability}

In measuring reliability coefficient, the different constructs were computed using the reliability procedure in SPSS 22. The reliabilities of the entire construct used in this study found to be above the standard set which is 0.70 (Nunnally, 1978). The range of Cronbach's alpha shows the reliability of the variables of research ranges from $\alpha=0.871$ to $\alpha=0.922$ in table 03 (Appendix B).

\section{Normality Test}

With the previous set guidelines for checking normality through Skewness and Kurtosis were used where positive and negative value indicates the direction of positive and negative relations respectively (Saunders, Lewis \& Thornhill, 2009) and the threshold values for justification were +/- 3 and +/- 10 for Skewness and Kurtosis respectively (Kline, 2005). In addition, table 04 (Appendix C) results that the mean for satisfaction (3.4) is the highest while for quality service (2.79) is the lowest, though highest dispersion goes with one stop service (1.04). The skewness and kurtosis are ranged from 0.023 and 0.958 , but within the expected values of skewness and kurtosis. Hence the data is normally distributed.

\section{Multi-collinearity Test}

To test the linear association among predictors and the degree of relationship, Pearson Correlation analysis has been used to check the issue of multicollinearity having score more than +/- 0.90 (Hair, Bush \& Ortinau, 2006).

From the table 05 (Appendix D) of correlation matrix, the highest coefficient value shown is 0.87 which is not close to the limit of multi-collinearity issues.

\section{Common Method Bias}

To check the common method biasness, the un-rotated Harman's single factor analysis was done owing to the suggestion of Hair, Hult, Ringle, Sarstedt \& Thiele (2017) [ with the condition of less than $50 \%$ of total variance explained by a factor] where found $12.10 \%$ of total variance explained by one factor meaning to satisfy the condition of less than $50 \%$.

\section{Demographic Analysis}

Out of 411valid respondents in the survey, there were $70 \%$ male and $30 \%$ female respondents. Most of the participants were traveling through Starline Services several times and aged between 20-50+ years where maximum percentage belonging to as $30-40$ years as $45 \%$, followed by $40-50$ years as $30 \%, 50+$ years as $10 \%$, and aged between 20-30 years were $13 \%$.

\section{Convergent Validity Analysis}

For the case of convergent validity, the higher the loading (More than 0.70), the better chance to avail acceptability where the threshold value is at least 0.50 (Hair, 
et al.2014). From the factor loading perspective, the minimum acceptable value is 0.60 which satisfied the condition as claimed by earlier literature.

With respect to the values of composite reliability (CR) and average variance extracted (AVE) for the selected variables, the minimum acceptable limit was more than equal to 0.50 (Lawson-Body \& Limayen, 2004). Again, this issue also be solved by having no values under 0.50 means to reasonable internal consistency.

Table 06: Composite Reliability (CR) and Average Variance Extracted (AVE)

\begin{tabular}{|l|r|r|}
\hline \multicolumn{1}{|c|}{ Items } & \multicolumn{1}{c|}{ CR } & \multicolumn{1}{c|}{ AVE } \\
\hline Satisfaction & 0.93 & 0.65 \\
\hline Loyalty & 0.90 & 0.57 \\
\hline Price & 0.92 & 0.63 \\
\hline Brand Belief & 0.87 & 0.50 \\
\hline Income & 0.86 & 0.51 \\
\hline One Stop Service & 0.89 & 0.57 \\
\hline Waiting Time & 0.88 & 0.52 \\
\hline Quality Service & 0.90 & 0.61 \\
\hline
\end{tabular}

To avoid the issue of discriminant validity, the value of AVE should be greater than the correlation value of that variables with other variables but Fornell \& Lacker (1981) suggested to consider the values lower than 0.50 of AVE if CR is more than 0.70 . For all the cases, the variables were out of concern by satisfying the conditions as per table 06 .

\section{Confirmatory Factor Analysis (CFA)}

Confirmatory factor analysis was used here to measure the construct validity of the model whereas convergent validity is for existence of construct determined by the correlations exhibited by independent measures of the construct. To assess convergent validity the loading estimates and construct reliability were investigated. In AMOS 22, convergent validity can be measured using the measurement model by determining the significant value of each item's estimated pattern coefficient on its posited underlying construct factor (Anderson \& Gerbing, 1988). To measure the uni-dimensionality, convergent and discriminant validity through AMOS 22, the CFA provides overall fit indices $(\chi 2=$ 32.971), chi-square degrees of freedom $=$ 15, RMSEA (Root Mean Square Error of Estimation $)=0.026$, GFI (Goodness of Fit Indices) $=0.947$, AGFI (Adjusted Goodness of Fit Indices) $=0.923$, CFI (Comparative Fit Indices) $=0.959$, and NNFI (Non-normed Fit Indices) $=0.962$. Here Goodness-of-fit of the final model indicated 'reasonable or good fit' or RMSEA $=0.026$. It is suggested that 0.05 $<$ RMSEA $<0.08$ is for good fit (Hair et.al, 2006). In this study, $C F I=0.959$ demonstrate reasonable fit. A rule of thumb for the CFI and the incremental indexes is that values greater than roughly 0.90 may indicate reasonably good fit of the researcher model $(\mathrm{Hu} \&$ Bentler, 1999). GFI $=1.0$ refers to perfect fit (Joreskog \& Sorbom, 1999). Therefore, a $\mathrm{GFI}=0.947$ indicates reasonably good fit if the researcher's model in this study. The AGFI of 0.923 indicates reasonably good fit of the researcher model. The NNFI (Non-normed Fit Indices) or TuckerLewis Index has been recommended a value of 0.90 or better for good fit (Bentler \& Bonett, 1980; Hair et.al., 2006). Thus, an NNFI $=0.962$ for this study implies good fit. From the above goodness-of-fit evaluation, confirmatory factor analysis for the final measurement model reasonably supported the model's fit.

\section{Measurement Model}

\section{Structural Equation Model (SEM)}

A structural model is fit to the data according to the model structure given in the figure 01(Appendix A). All the paths are assessed to find significant positive standardized path coefficients. The goodness of fit indices for the final 
structure model, shown in the bottom part of table 07 (Appendix E), suggests a good fit to the data: small ratio of chi-square to degree of freedom $(<2)$, great values of GFI, AGFI, CFI, NFI (>0.9) and RMSEA values $(<0.05)$.

Table 08: Standardized Regression Weights

\begin{tabular}{|l|r|}
\hline & Estimate \\
\hline Satisfaction $\leftarrow$ Income & .335 \\
\hline Loyalty $\leftarrow$ Income & .132 \\
\hline Satisfaction $\leftarrow$ Price & .084 \\
\hline Loyalty $\leftarrow$ Price & .224 \\
\hline $\begin{array}{l}\text { Satisfaction } \leftarrow \quad \text { Quality } \\
\text { Service }\end{array}$ & .173 \\
\hline \begin{tabular}{l} 
Loyalty $\leftarrow$ Quality Service \\
\hline $\begin{array}{l}\text { Satisfaction } \leftarrow \text { Brand } \\
\text { Belief }\end{array}$
\end{tabular} & .224 \\
\hline Loyalty $\leftarrow$ Brand Belief \\
\hline $\begin{array}{l}\text { Satisfaction } \leftarrow \text { One Stop } \\
\text { Service }\end{array}$ \\
\hline $\begin{array}{l}\text { Loyalty } \leftarrow \quad \text { One Stop } \\
\text { Service }\end{array}$ \\
\hline $\begin{array}{l}\text { Satisfaction } \leftarrow \quad \text { Waiting } \\
\text { Time }\end{array}$ \\
\hline Loyalty $\leftarrow$ Waiting Time \\
\hline Loyalty $\leftarrow$ Satisfaction & .218 \\
\hline
\end{tabular}

In accordance with the parameter estimates shown in figure 02 (Appendix F) and table 08 , all the factors have positive effect on both satisfaction and loyalty and these findings are proposed in $\mathrm{H} 1$ to $\mathrm{H} 12$. The analysis results also yield that satisfaction related positively and significantly with loyalty and this finding proposed in $\mathrm{H} 13$.

\section{The Hypothesized Casual Structure Model}

As shown in table 09 (Appendix G), the regression weight of income to satisfaction $(\mathrm{t}=6.510 ; \mathrm{p}<0.05)$; income to loyalty $(\mathrm{t}=2.664 ; \mathrm{p}<0.05)$; price to satisfaction $(\mathrm{t}=2.632 ; \mathrm{p}<0.05)$; price to loyalty $(\mathrm{t}=4.956 ; \mathrm{p}<0.05)$; quality service to satisfaction ( $\mathrm{t}=3.374 ; \mathrm{p}<0.05)$; quality service to loyalty $(\mathrm{t}=4.847 ; \mathrm{p}<0.05)$; brand belief to satisfaction $(\mathrm{t}=5.756 ; \mathrm{p}<$ $0.05)$; brand belief to loyalty $(\mathrm{t}=6.811 ; \mathrm{p}<$ $0.05)$; one stop service to satisfaction $(\mathrm{t}=4.242 ; \mathrm{p}<0.05)$; one stop service to loyalty $(\mathrm{t}=2.613 ; \mathrm{p}<0.05)$; waiting time to satisfaction ( $\mathrm{t}=8.490 ; \mathrm{p}<0.05)$; waiting time to loyalty $(\mathrm{t}=6.253 ; \mathrm{p}<0.05)$; satisfaction to loyalty $(\mathrm{t}=4.028 ; \mathrm{p}<0.05)$ were significant. This indicated that the factors had significant direct effect on satisfaction \& loyalty, and satisfaction had direct effect on loyalty. The estimation results in table 09 (Appendix G) indicate that the thirteen hypotheses, H1(Income to Satisfaction), H2 (Income to Loyalty), H3 (Price to Satisfaction), H4 (Price to Loyalty), H5 (Quality Service to Satisfaction), H6 (Quality Service to Loyalty), H7 (Brand Belief to Satisfaction), H8 (Brand Belief to Loyalty), H9 (One Stop Service to Satisfaction), H10 (One Stop Service to Loyalty), H11 (Waiting Time to Satisfaction), H12 (Waiting Time to Loyalty), and H13 (Satisfaction to Loyalty) are supported, with path coefficients of $0.299,0.101,0.070,0.161$, $0.160,0.176,0.253,0.241,0.189,0.091$, $0.388,0.249$, and 0.213 respectively.

\section{Discussion}

The transport and travel services of Bangladesh provide service variety in context to the varying nature of demand and buying power. The customers prone to quality service at a fair cost are tremendously wanting. Though the study covered only a specific region with limited number of respondents, the intensity of customers toward the brand is not negligible. The maximum factors affecting both the satisfaction and loyalty were brand belief, one stop service, 
quality service and waiting time to get the added advantage for the Starline services.

The earlier research of May, GrantMuller, Marsden, \& Thanos (2008) considered the quality service and got the significant involvement with satisfaction which is identical to this study. In addition, another study of Eboli, Forciniti, \& Mazzulla, (2018) also supports the similarities about the findings. This is, basically certified the strength of the Starline service and keeping passengers retained toward their traveling service.

Based on the earlier research done by Eboli, Forcinitu \& Mazzulla (2018), the dimensions set for quality assessment of the services are quite significant with this study. By the similarities with the findings of the Bakti \& Sumaedi (2015), the quality services that identified through constituents like safety and other issues are also found quite influential accordingly with the hypotheses. However, this paper re-confirms the hypothesis headed to satisfaction and loyalty through quality service, income with the similarities from the earlier researches of de Oña \& de Oña (2015) and Lai \& Chen (2011). So, it is certainly meant that the higher the positivity towards the services, the higher the satisfaction, which ultimately leads to satisfaction. These hypotheses were related to the findings of Jomnonkwao \& Ratanavaraha (2016)'s study. In connection to satisfaction, the income of the passengers also influences the satisfaction having resemblance to past study of Blainey \& Mulley (2013).

As per Research conducted by Flavian, Martinez, \& Polo (2001), trust is considered to be a good indicator for satisfaction which is similar with this study where trust positively related with satisfaction and loyalty. Again, this result is compatible with the research on Park, Robertson \& Wu (2004).On the other hand, the reliability of Starline services and its brand image were justified by the current situation having keen support from the study of Park, Robertson \& Wu (2004) supposing to positive image intend to attract passenger attention. In reality, the factors imposed to be a monopoly business concern in this territory particularly on passenger travel service by quality service. The trust achieved by the brand (Starline) and one stop service got unique psychological positioning among the customers. The future researcher can justify the situation with more sample size and identify such situation in other regions of the country.

On the other hand, the hypothesis that visualized the price/fare impact on satisfaction was initiated quite satisfactory result parallel to the study of Chen, Schonfeld, \& Miller-Hooks (2016). This study is also consistent with the study of Suryani, Chou, \& Chen (2010) which was studied for changing behavioral intention. The relationship between satisfaction and loyalty what is studied here is also justified with much more analogous to earlier research of Sangadji \& Sopiah (2013) for identical perception. It ultimately, confirmed that the higher the satisfaction the higher the loyalty. For intercity bus carrier to get a competitive advantage, effective marketing strategies has the key role players to endure in the long-distance transportation market whereas loyalty worked as a measure (Flavian, 2001). Though the study focused the loyalty on the existing and previously considered for travel services, but this loyalty preference is also influential to potential customers by advocacy, resistance to change and relative preference of the brand in competition (Butcher, Sparks, \& O'Callaghan, 2001). Ultimately, these non-responding situations of other service providers in all aspects of quality services in this region are contributing too much to become Starline as a monopoly business concern but these will be very positive prospective 
investment options on the other side for other travel service providers.

\section{Conclusion}

This study proposed and analyzed the quality service, income, and other key factors and found demanding for passengers' satisfaction and loyalty. But few unprecedented and neglected factors like passenger's lifestyle, competition, emergency, service accessibility, cleanliness, staff hospitality, and safe journey etc. were unable to materialize depending on the keen relevancy with Starline services. In addition, the supposition in view of immaterialized items/ factors might be considered as indispensable factors what was hidden with the existing issues in future study. Moreover, the considerable factors are not augmentation of the existing services what was supposed to earlier research, but these services had a very good impact on the true identity of the perceived value as passengers expected for transport service.

The firm should concern over the issues raised should be under cognizance right now or to be addressed later on. The complaint box and periodic survey among the passengers should regularly be carried out for receiving proper information from the passengers. From the very truest sense, the frontier problems of other transport services force the passengers to switch to Starline with no doubt. The applicability of this research can be contributed to the enhancement of the industry revenue. These special services what were considered in this study upgrade the existing services. Last but not least, amid criticism against the price hike due to supply shortage or handling the situational demand or tackle it, passengers are eagerly accepted the causes and overturn to the loyalty toward Starline again.

\section{References}

Anderson, J. C., \& Gerbing, D. W. (1988). Structural equation modeling in practice: A review and recommended two-step approach. Psychological bulletin, 103(3), 411.

http://dx.doi.org/10.1007/BF02294170.

Anderson, J. C., \& Gerbing, D. W. (1988). Structural equation modeling in practice: A review and recommended two-step approach. Psychological bulletin, 103(3), 411.

http://dx.doi.org/10.1007/BF02294170.

Bakti, I. G. M. Y., \&Sumaedi, S. (2015). P-TRANSQUAL: a service quality model of public land transport services. International Journal of Quality \& Reliability Management, 32(6), 534558. https://doi.org/10.1108/IJQRM-062013-0094

Ballester, E. D., \& Alemán, J. L. M. (1999). Estrategias para las empresas exportadoras murcianas. Gestión: revista de economía, (10), 19-26.

Beatty, S.E., Kahle, L.R., and Homer, P. (1988), The Involvement - Commitment Model: Theory and Implication. Journal of Business Research, 16(2), 149 - 167. https://doi.org/10.1016/0148-

2963(88)90039-2

Bentler, P. M., \& Bonett, D. G. (1980). Significance tests and goodness of fit in the analysis of covariance structures. Psychological bulletin, 88(3), 588. DOI: 10.1037/0033-2909.88.3.588

Blainey, S., \& Mulley, C. (2013, October). Using Geographically Weighted Regression to forecast rail demand in the Sydney Region. In Australasian Transport Research Forum, Brisbane.

Bloemer, J. M., \& Kasper, H. D. (1995). The complex relationship between consumer satisfaction and brand loyalty. Journal of economic 
psychology, 16(2), 311-329. https://doi.org/10.1016/01674870(95)00007-B

Brady, M. K., \& Cronin Jr, J. J. (2001). Some new thoughts on conceptualizing perceived service quality: a hierarchical approach. Journal of marketing, 65(3), 3449.

https://doi.org/10.1509/jmkg.65.3.34.183 34

Butcher, K., B. Sparks, and F. O'Callaghan (2001), Evaluative and Relational Influences on Service Loyalty. International Journal of Service Industry Management, 12(4), 310-327. https://doi.org/10.1108/09564230110405 253

Buttle, F. (1996). SERVQUAL: review, critique, research agenda. European Journal of marketing, 30(1), 8-32. https://doi.org/10.1108/03090569610105 762

Carruthers, R., Dick, M., \& Saurkar, A. (2005). Affordability of public transport in developing countries.

Chen, L., Schonfeld, P., \& Miller-Hooks, E. (2016). Welfare maximization for bus transit systems with timed transfers and financial constraints. Journal of Advanced Transportation, 50(4), 421-433. https://doi.org/10.1002/atr.1331

Chen, L., Schonfeld, P., \& Miller-Hooks, E. (2016). Welfare maximization for bus transit systems with timed transfers and financial constraints. Journal of Advanced Transportation, 50(4), 421-433. https://doi.org/10.1002/atr.1331

Chou, S. Y. (2012). Online reviews and pre-purchase cognitive dissonance: A theoretical framework and research propositions. Journal of Emerging Trends in Computing and Information Sciences, 3(2), 199-204.

Cronin Jr, J. J., \& Taylor, S. A. (1994). SERVPERF versus SERVQUAL: reconciling performance-based and perceptions-minus-expectations measurement of service quality. Journal of marketing, 58(1), 125-131. https://doi.org/10.1177/00222429940580 0110

Cronin Jr, J. J., \& Taylor, S. A. (1994). SERVPERF versus SERVQUAL: reconciling performance-based and perceptions-minus-expectations measurement of service quality. Journal of marketing, 58(1), 125-131. https://doi.org/10.1177/00222429940580 0110

Cronin, J. J., Jr., M. K. Brady, and G. T. M. Hult. (2000), Assessing the Effects of Quality, Value, and Customer Satisfaction on Customer Behavioral Intentions in Service Environments. Journal of Retailing, 76(2), 193-218. https://doi.org/10.1016/S00224359(00)00028-2

De Oña, J., \& de Oña, R. (2014). Quality of service in public transport based on customer satisfaction surveys: A review and assessment of methodological approaches. Transportation Science, 49(3), 605-622. https://doi.org/10.1287/trsc.2014.0544

Deb, S., \& Ahmed, M. A. (2018). Determining the service quality of the city bus service based on users' perceptions and expectations. Travel Behaviour and Society, 12, 1-10. https://doi.org/10.1016/j.tbs.2018.02.008

Dell'Olio, L., Ibeas, A., \& Cecin, P. (2011). The quality of service desired by public transport users. Transport Policy, 18(1), 217-227. https://doi.org/10.1016/j.tranpol.2010.08. 005

Dick, A. S., and K. Basu. (1994). Consumer Loyalty: Toward an Integrated Conceptual Framework. Journal of the Academy of Marketing Science, 22(2), 99113. 
https://doi.org/10.1177/00920703942220 01

Eboli, L., \& Mazzulla, G. (2011). A methodology for evaluating transit service quality based on subjective and objective measures from the passenger's point of view. Transport Policy, 18(1), 172-181. DOI: 10.1016/j.tranpol.2010.07.007

Eboli, L., Forciniti, C., \& Mazzulla, G. (2018). Formative and reflective measurement models for analysing transit service quality. Public Transport, 10(1), 107-127.

Efthymiou, D., Kaziales, M., Antoniou, C., \& Tyrinopoulos, Y. (2014). Measuring the Effects of Economic Crisis on Users' Perceptions of Public Transport Quality. Transportation Research Record, 2415(1), 1-12.

Enoch, M.P. (2003). Pooling together: why the vanpool works in the US and the Netherlands. Traffic engineering and control, 44 (1), 12-14.

Flavián, C., Martínez, E., \& Polo, Y. (2001). Loyalty to grocery stores in the Spanish market of the 1990s. Journal of Retailing and Consumer Services, 8(2), 85-93.

Fornell, C. R., \& Lacker, D. F. (1981). Two structural equation models with unobservable variables and measurement error. Journal of Marketing Research, 18, 382-388.

Fornell, C., M. D. Johnson, E. W. Anderson, J. Cha, and B. E. Bryant. (1996). The American Customer Satisfaction Index: Nature, Purpose, and Findings. Journal of Marketing, 60(1), 718.

Freitas, A. L. P. (2013). Assessing the quality of intercity road transportation of passengers: An exploratory study in Brazil. Transportation Research Part A: Policy and Practice, 49, 379-392.
Friman, M., Edvardsson, B., \& Gärling, T. (2001). Frequency of negative critical incidents and satisfaction with public transport services. I. Journal of Retailing and Consumer Services, 8(2), 95-104.

Gallarza, M. G., \& Saura, I. G. (2006). Value dimensions, perceived value, satisfaction and loyalty: an investigation of university students' travel behaviour. Tourism management, 27(3), 437-452.

Ghalehkhondabi, I., Ardjmand, E., Young, W. A., \& Weckman, G. R. (2019). A review of demand forecasting models and methodological developments within tourism and passenger transportation industry. Journal of Tourism Futures, 5(1), 75-93.

Hair, Jr.(Joseph F.), Bush, R. P., \& Ortinau, D. J. (2006). Marketing research: Within a changing information environment. McGraw-Hill.

Hair Jr, J. F., Sarstedt, M., Hopkins, L., \& G. Kuppelwieser, V. (2014). Partial least squares structural equation modeling (PLS-SEM) An emerging tool in business research. European Business Review, 26(2), 106-121.

Hair, J. F., Hult, G. T. M., Ringle, C. M., Sarstedt, M., \& Thiele, K. O. (2017). Mirror, mirror on the wall: a comparative evaluation of composite-based structural equation modeling methods. Journal of the Academy of Marketing Science, 45(5), 616-632. doi:10.1007/s11747-017-0517$\mathrm{x}$

Hellier, P. K., Geursen, G. M., Carr, R. A., \& Rickard, J. A. (2003). Customer repurchase intention: A general structural equation model. European Journal of Marketing, 37(11/12), 1762-1800. DOI: 10.1108/03090560310495456

Holloway, J. C. (2004), Marketing for Tourism, Prentice Hall, New York. 
Hu, K. C., \& Jen, W. (2006). Passengers' perceived service quality of city buses in Taipei: scale development and measurement. Transport Reviews, 26(5), 645-662.

https://doi.org/10.1080/01441640600679 482

Hu, L. T., \& Bentler, P. M. (1999). Cutoff criteria for fit indexes in covariance structure analysis: Conventional criteria versus new alternatives. Structural equation modeling: a multidisciplinary journal, 6(1), 1-55. https:// https://doi.org/10.1080/10705519909540 118

Jo Hatch, M., \& Schultz, M. (2003). Bringing the corporation into corporate branding. European Journal of marketing, 37(7/8), 1041-1064. https://doi.org/10.1108/03090560310477 654

Jomnonkwao, S., \& Ratanavaraha, V. (2016). Measurement modelling of the perceived service quality of a sightseeing bus service: An application of hierarchical confirmatory factor analysis. Transport Policy, 45, 240-252. DOI: 10.1016/j.tranpol.2015.04.001

Jöreskog, K. G., \& Sörbom, D. (1993). LISREL 8: Structural equation modeling with the SIMPLIS command language. Scientific Software International.

Kline, R. B. (2005). Principles and practice of structural equation modeling 2nd ed. New York: Guilford. https://doi.org/10.1177/10497315093369 86

Lai, W. T., \& Chen, C. F. (2011). Behavioral intentions of public transit passengers - The roles of service quality, perceived value, satisfaction and involvement. Transport Policy, 18(2), 318-325. DOI: 10.1016/j.tranpol.2010.09.003
Laws, E. (1995), Tourist Destination Management: Issues, Analysis and Policies, London, Routledge. https://doi.org/10.1177/00472875950340 0239

Lawson-Body, A., \& Limayem, M. (2004). The impact of customer relationship management on customer loyalty: The moderating role of web site characteristics. Journal of ComputerMediated Communication, 9(4), JCMC944.

https://doi.org/10.1111/j.1083-

6101.2004.tb00295.x.

Liao, K. H., \& Hsieh, M. F. (2011, July). Statistic exploring the casual relationships between service quality, brand image, customer satisfaction and customer loyalty on the leisure resort industry. In Service Management (IRSSM-2) in 2011 proceedings of the 2 nd International Research Symposium (pp. 506-515).

Litman, Todd (2013), Understanding Transport Demands and Elasticities, How Prices and Other Factors affect Travel behavior, Victoria Transport Policy Institute, Available at: www.vtpi.org.

Logsdon, J. M., \& Wood, D. J. (2002). Reputation as an emerging construct in the business and society field: An introduction. Business \& Society, 41(4), 365-370.

https://doi.org/10.1177/00076503022387 73

Mahmud, S.M. Sohel., Rahman, Mohammad Wahidur., and Hasanat-ERabbi, Shahnewaz (2012), Transport System in Bangladesh: Issues and Options for Sustainable Development, Working Paper, Accident Research Center (ARC), BUET, Dhaka, Bangladesh.

Mai, A. (2013). The internet of cars: A catalyst to unlock societal benefits of transportation. 
March, R. G., \& Woodside, A. G. (2005), Tourism Behavior: Travelers' Decisions and Actions, CABI Publishing, Cambridge.

doi:10.1016/j.annals.2004.07.012

May, A. D., Grant-Muller, S. M., Marsden, G., \& Thanos, S. (2008). Improving the collection and monitoring of urban travel data: An international review. In TRB 87th Annual Meeting Compendium of Papers DVD. National Academy of Sciences. https://doi.org/10.3311/PPtr.12072

Morgan, R. M., \& Hunt, S. D. (1994). The commitment-trust theory of relationship marketing. Journal of marketing, 58(3), 20-38. DOI: $10.2307 / 1252308$

Morgan, R. M., \& Hunt, S. D. (1994). The commitment-trust theory of relationship marketing. Journal of marketing, 58(3), 20-38. DOI: $10.2307 / 1252308$

Nguyen, N., \& Leblanc, G. (2001). Corporate image and corporate reputation in customers' retention decisions in services. Journal of retailing and Consumer Services, 8(4), 227-236. DOI: 10.1016/S0969-6989(00)00029-1

Nunnally, J. C. (1978). Psychometric Theory. NP: McGraw-Hill. https://doi.org/10.3102/00028312005003 431

Oliver, R. L. (1997). Satisfaction, a Behavioral Perspective on the Consumer. The McGrawHill Companies. Inc., New York.

https://doi.org/10.4324/9781315700892

Ostrowski, P. L., T. V. O'Brien, and G. L. Gordon. (1993). Service Quality and Customer Loyalty in the Commercial Airline Industry. Journal of Travel Research, 32, 16-24. https://doi.org/10.1177/00472875930320 0203

Park, J. W., Robertson, R., \& Wu, C. L. (2004). The effect of airline service quality on passengers' behavioural intentions: a Korean case study. Journal of Air Transport Management, 10(6), 435439. DOI: 10.1016/j.jairtraman.2004.06.001

Rezaei, S., Mazaheri, E., \& Azadavar, R. (2017). Determinants of experienced tourists' satisfaction and actual spending behavior: A PLS path modelling approach. International Journal of Culture, Tourism and Hospitality Research, 11(2), 157-181. https://doi.org/10.1108/IJCTHR-092015-0107

Roch, C. H., \& Poister, T. H. (2006). Citizens, accountability, and service satisfaction: The influence of expectations. Urban Affairs Review, 41(3), 292-308. https://doi.org/10.1177/10780874052811 24

Rystam, Å. (1998). Färdmedelsvalet och valprocessen för lokala resor till regional tågtrafik: en analys med betoning på cykelns betydelse. LTH LUTVDG/(TVTT-1017-200) Lund.

Sangadji, E. M., \& Sopiah, (2013). Consumer Behavior: Perilaku Konsumen dan Strategi Pemasaran Jilid 2. Jakarta: Erlangga.

Saunders, M., Lewis, P., Thornhill, A., \& Wang, C. (2009). Analysing qualitative Saunders, M., Lewis, P., Thornhill, A., \& Wang, C. (2009). Analysing qualitative data. Research methods for business students. 5th edn. Harlow, Essex, UK: Pearson Education Ltd, 480-525.

Semeida, A. M. (2014). Derivation of travel demand forecasting models for low population areas: the case of Port Said Governorate, North East Egypt. Journal of Traffic and Transportation Engineering (English Edition), 1(3), 196-208. https://doi.org/10.1016/S20957564(15)30103-3 
Shaaban, K., \& Khalil, R. F. (2013). Investigating the customer satisfaction of the bus service in Qatar. Procedia-Social and Behavioral Sciences, 104, 865-874. https://doi.org/10.1016/j.sbspro.2013.11. 181

Shoup, D. (2017). The high cost of free parking: Updated edition. Routledge. https://doi.org/10.4324/9781351179782.

Stank, T. P., Goldsby, T. J. and Vickery, S. K. (1999) .Effect of Service Supplier Performance on Satisfaction and Loyalty of Store Managers in the Fast Food Industry. Journal of Operations Management, 17, 429-447. https://doi.org/10.1016/S02726963(98)00052-7

SumChau, V., \& Ngai, L. W. (2010). The youth market for internet banking services: perceptions, attitude and behaviour. Journal of Services Marketing, 24(1), 42-60. https://doi.org/10.1108/08876041011017 880 .

Suman, H. K., Bolia, N. B., \& Tiwari, G. (2018). Perception of potential bus users and impact of feasible interventions to improve quality of bus services in Delhi. Case Studies on Transport Policy, 6(4), 591-602. https://doi.org/10.1016/j.cstp.2018.07.00 9.

Suryani, E., Chou, S. Y., \& Chen, C. H. (2010). Air passenger demand forecasting and passenger terminal capacity expansion: A system dynamics framework. Expert Systems with Applications, 37(3), 2324-2339. doi:10.1016/j.eswa.2009.07.041

Tabachnick, B. G., Fidell, L. S., \& Ullman, J. B. (2007). Using multivariate statistics (Vol. 5). Boston, MA: Pearson.

Thompson, K. Schofield, P. (2002). The Dimensions of Quality of Urban Public
Transport-An Overseas Visitor Perspective on Greater Manchester. Tourism Destination Planning, 42, 281281.

Tyrinopoulos, Y., \& Antoniou, C. (2008). Public transit user satisfaction: Variability and policy implications. Transport Policy, 15(4), 260-272. DOI: 10.1016/j.tranpol.2008.06.002

Van Lierop, D., \& El-Geneidy, A. (2016). Enjoying loyalty: The relationship between service quality, customer satisfaction, and behavioral intentions in public transit. Research in Transportation Economics, 59, 50-59. https://doi.org/10.1016/j.retrec.2016.04.0 01

Van Phuong, N., \& Hieu, N. T. (2018). A Study on Factors Affecting Customer Intention to Use the Express Bus. VNU Journal of Science: Economics and Business, $34(5 \mathrm{E})$. https://doi.org/10.25073/2588-

1108/vnueab.4167

Vodopivec, N., \& Miller-Hooks, E. (2017). An optimal stopping approach to managing travel-time uncertainty for time-sensitive customer pickup. Transportation Research Part B: Methodological, 102, 22-37. DOI: 10.1016/j.trb.2017.04.017 


\section{Appendices}

\section{Appendix A}

Figure 01: Conceptual Model

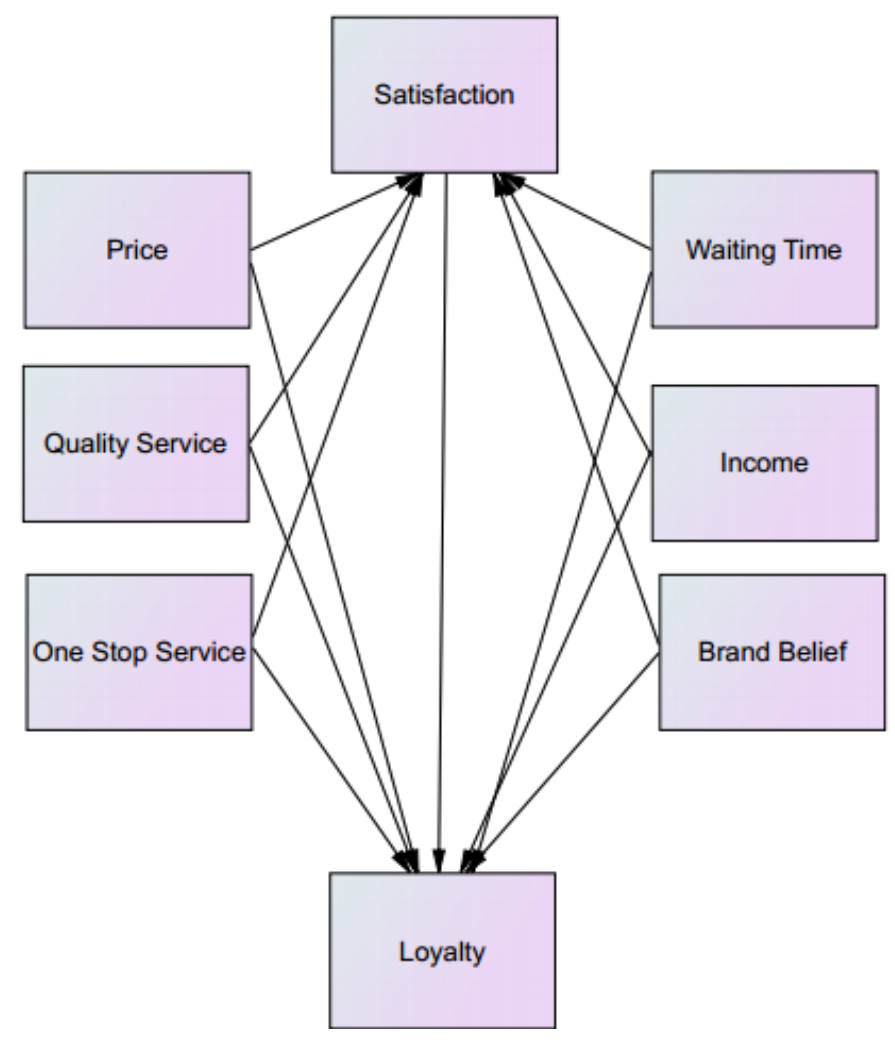

\section{Appendix B}

Table 03: Reliability Statistics

\begin{tabular}{|l|r|}
\hline \multicolumn{1}{|c|}{ Items } & \multicolumn{2}{c|}{$\begin{array}{c}\text { Cronbach's Alpha Based on } \\
\text { Standardized Items }\end{array}$} \\
\hline Loyalty & .889 \\
\hline Waiting Time & .883 \\
\hline Brand Belief & .871 \\
\hline One Stop Service & .892 \\
\hline Satisfaction & .922 \\
\hline Income & .888 \\
\hline Price & .915 \\
\hline Quality Service & .904 \\
\hline
\end{tabular}




\section{Appendix C}

Table 04: Descriptive Statistics

\begin{tabular}{|l|r|r|r|r|}
\hline \multicolumn{1}{|c|}{ Variables } & Mean & \multicolumn{1}{c|}{ S.D. } & \multicolumn{1}{c|}{ Skew. } & \multicolumn{1}{c|}{ Kurt. } \\
\hline Loyalty & 3.06 & 0.93 & 0.254 & 0.25 \\
\hline Waiting Time & 2.9 & 1.01 & 0.217 & 0.023 \\
\hline Brand Belief & 3.02 & 0.98 & 0.357 & 0.78 \\
\hline One Stop Service & 2.97 & 1.04 & 0.459 & 0.294 \\
\hline Satisfaction & 3.4 & 0.99 & 0.254 & 0.09 \\
\hline Income & 2.88 & 0.79 & 0.315 & 0.442 \\
\hline Price & 3.07 & 0.73 & 0.412 & 0.309 \\
\hline Quality Service & 2.79 & 0.84 & 0.598 & 0.958 \\
\hline
\end{tabular}

\section{Appendix D}

Table 05: Correlation

\begin{tabular}{|c|c|c|c|c|c|c|c|c|}
\hline & 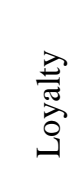 & 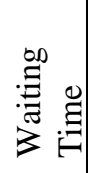 & 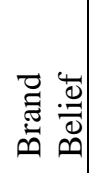 & 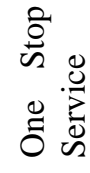 & 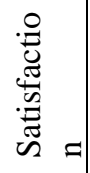 & $\underset{\Xi}{\mathscr{0}}$ & $\stackrel{\mathscr{U}}{\Xi}$ & 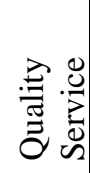 \\
\hline Loyalty & 1 & 0.7 & 0.75 & 0.68 & 0.87 & 0.78 & 0.8 & 0.68 \\
\hline Waiting Time & 0.7 & 1 & 0.56 & 0.5 & 0.65 & 0.34 & 0.28 & 0.21 \\
\hline Brand Belief & 0.75 & 0.56 & 1 & 0.66 & 0.65 & 0.3 & 0.31 & 0.32 \\
\hline One Stop Service & 0.68 & 0.5 & 0.66 & 1 & 0.63 & 0.5 & 0.4 & 0.34 \\
\hline Satisfaction & 0.87 & 0.65 & 0.65 & 0.63 & 1 & 0.73 & 0.64 & 0.55 \\
\hline Income & 0.78 & 0.34 & 0.3 & 0.5 & 0.73 & 1 & 0.11 & 0.77 \\
\hline Price & 0.8 & 0.28 & 0.31 & 0.4 & 0.64 & 0.11 & 1 & 0.82 \\
\hline Quality Service & 0.68 & 0.21 & 0.32 & 0.34 & 0.55 & 0.77 & 0.82 & 1 \\
\hline
\end{tabular}

\section{Appendix E}

Table 07: Goodness-of-fit results of the study

\begin{tabular}{|l|r|r|r|}
\hline \multicolumn{1}{|c|}{ Goodness-of-fit statistics } & & Values & $\begin{array}{c}\text { Desired range of } \\
\text { values for a good fit }\end{array}$ \\
\hline Chi-square test & $\chi^{2}$ & 32.971 & $\geq 0$ \\
\hline Degrees of freedom & Df & 15 & 2 to 5 \\
\hline Chi-square/ degrees of freedom ration & $\chi^{2} / \mathrm{df}$ & 2.19 & $>0.90$ \\
\hline Goodness of fit index & GFI & 0.947 & $<0.08$ \\
\hline Root mean square error of approximation & RMSEA & 0.026 & $>0.90$ \\
\hline $\begin{array}{l}\text { Incremental fit measures } \\
\text { Adjusted good-of-fit index }\end{array}$ & AGFI & 0.923 & $>0.90$ \\
\hline Tucker-Lewis Index & TLI & 0.962 & $>0.95$ \\
\hline Comparative fit index & CFI & 0.959 & $>0.90$ \\
\hline Normed fit index & NFI & 0.939 & \\
\hline
\end{tabular}




\section{Appendix F}

\section{Figure 02: Standardized estimates}

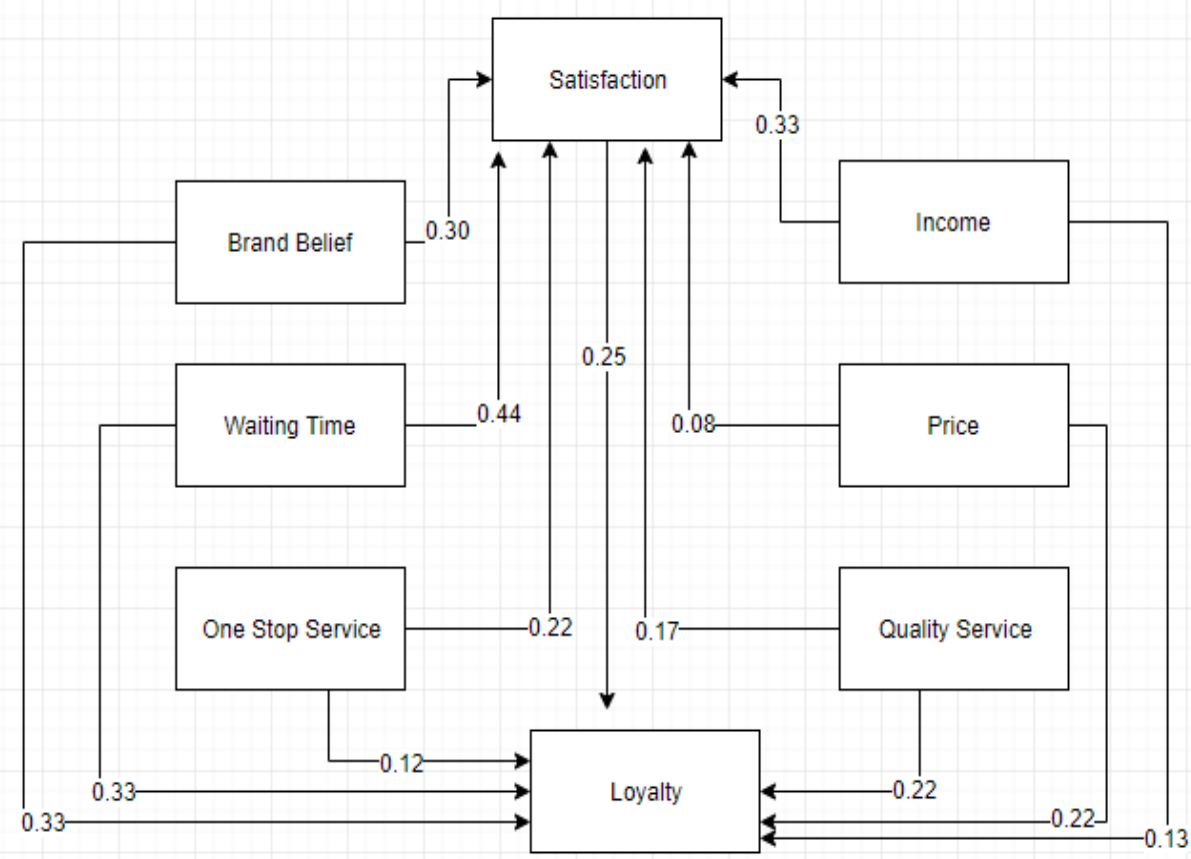

\section{Appendix G}

Table 09: Summary of Hypothesis Testing Results

\begin{tabular}{|c|c|c|c|c|}
\hline & Est. & S.E. & C.R. & $\mathrm{P}$ \\
\hline Satisfaction $\leftarrow$ Income & .299 & .046 & 6.510 & $* * *$ \\
\hline Loyalty $\leftarrow$ Income & .101 & .038 & 2.664 & .008 \\
\hline Satisfaction $\leftarrow$ Price & .070 & .043 & 2.632 & .008 \\
\hline Loyalty $\leftarrow$ Price & .161 & .032 & 4.956 & $* * *$ \\
\hline Satisfaction $\leftarrow$ Quality Service & .160 & .047 & 3.374 & $* * *$ \\
\hline Loyalty $\leftarrow$ Quality Service & .176 & .036 & 4.847 & $* * *$ \\
\hline Satisfaction $\leftarrow$ Brand Belief & .253 & .044 & 5.756 & $* * *$ \\
\hline Loyalty $\leftarrow$ Brand Belief & .241 & .035 & 6.811 & $* * *$ \\
\hline Satisfaction $\leftarrow$ One Stop Service & .189 & .045 & 4.242 & $* * *$ \\
\hline Loyalty $\leftarrow$ One Stop Service & .091 & .035 & 2.613 & .009 \\
\hline Satisfaction $\leftarrow$ Waiting Time & .388 & .046 & 8.490 & $* * *$ \\
\hline Loyalty $\leftarrow$ Waiting Time & .249 & .040 & 6.253 & $* * *$ \\
\hline Loyalty $\leftarrow$ Satisfaction & .213 & .053 & 4.028 & $* * *$ \\
\hline
\end{tabular}

Note: S.E. $=$ Standard error; C.R. $=$ Critical ratio, $*$ p $<0.01$ 